\title{
The ancient and contemporary geophysical stress field in a calcareous mountain-range
}

\author{
Adrian E. SCheIDEgGer $(*)$
}

Received on June 11, 1974

\begin{abstract}
Summary. - The stress systems which are and have been active in a well-defined calcareous mountain massif (the Ilochkonig massif in Austria) have been determined: (I) from joint orientations in the Paleozoic basement, (II) from joint orientations in the calcareous superstructure and (III) from in situ stress measurements in a mine beneath the massif. It was found (I) that the stresses which produced the Paleozoic joint system is quite distinct from the other systems active in the area, (II) that the joints in the superstructure correspond to a stress system that is in conformity with the general north-south thrust thought to have created the Alps and (III) that the stresses measured in situ represent nothing but the effect of the presentday overburden topography.
\end{abstract}

Riassunto. - I sistemi di sforzi che sono e sono stati attivi in un massiccio montnoso calcareo ben definito, quale il massiccio di Iochkïnig in Austria, sono stati determinati come segue: (I) dagli orientamenti di giunzioni nel basamento Paleozoico; (II) dagli orientamenti di giunzioni nella sovrastruttura calcarea; III) dalla misura di sforzi in situ effettuata in una miniera al disotto del massiccio. is stato constatato che: (I) gli sforzi che hanno prodotto il sistema di giunzione nel Paleozoico sono nettamente distinti da altri sistemi attivi nella zona; (II) le giunzioni nella sovrastruttura corrispondono ad un sistema di sforzi conforme alla spinta generale Nord-Sud, spinta da cui si ritiene abbiano avuto origine le Alpi: (III) gli sforzi misurati in situ rappresentano soltanto leffetto dell attuale topografia sovrastante.

(*) Institut für Geophysik, Technische Hochschule Vienna, Austria. 


\section{1. - Intronuction}

It is well known that the tectonic stress system (past and present) of a region has been responsible for the geodynamic processes having occurred in that region. Unfortunately, unlike other geophysical fields, it is still rather difficult to obtain determinations of the stress field, partly because the latter is a tensorial quantity that has to be described, in principle, by six components at each point. Thus, although direct measurements of the present-day stress field can be made, they require much eflort.

Nevertheless, there are a number of indirect methods for ascertaining the nature of the past and present tectonic stress field from its effects. Thus, the geomorphology of a mountain range has been sculptured in essence by stresses. Furthermore, all rocks contain joints which also are a result of the response of the rock to stresses. From a consideration of the morphology and the joints in a mountain range, statements regarding the stresses that produced the features in question can therefore be marle.

The present investigation represents an attempt to determine the geophysical stress field and its history in a well-defined mountain massif. An effort has been made to obtain information on the stress field from geomorphological investigations, from an analysis of the prevailing joint systems as well as from direct measurements. The requirements for an area suitable for investigation were therefore that it was a reasonably self-contained unit, that it was accessible for field investigations and that access was provided to its interior by mining works so that the stresses could be measured directly. As a suitable object for the study answering all these requirements, the Hochkonig massiv of Austria was chosen. The management of the copper mine at Mitterberg enabled us to make the direct stress measurements below ground. The whole study was supported by the Austrian Academy of Sciences as a contribution to the International Geodynamics Project. The results reported here are based upon the incessant efforts of many scientists. Thus, Dr. W. Fürlinger, Mr. R. Lahodynsky and I). F. Pausweg did most of the geological work, Dr. E. Gerber made the basic geomorphological investigations, and Dr. E. Brückl, Mr. P. Carniel and Mr. Roch were involved in the direct stress measurements. Without the support of these coworkers, the writer could not have completed the present study. 


\section{2. - IDESCRIPTION AND GEOLOGY OF THE AREA}

The area investigated is in Salzburg province of Austria in the South of the Northern Calcareous Alps. A sketch-map of the region is shown in Figure 1. The Hochkonig represents a single detached mountain massif; a general view thereof, looking toward the north, is shown in Figure 2.

Geologically, the basement of the massif is formed by metamorphic Paleozoic series of greywackes; upon it, Triassic layers are situated. The whole pattern of the sequence of the layers is shown in Table 1; a schematic geological cross section is given in Figure 3.

Table 1 - Sequence OF LAYERS - HoCHKöNig AREA

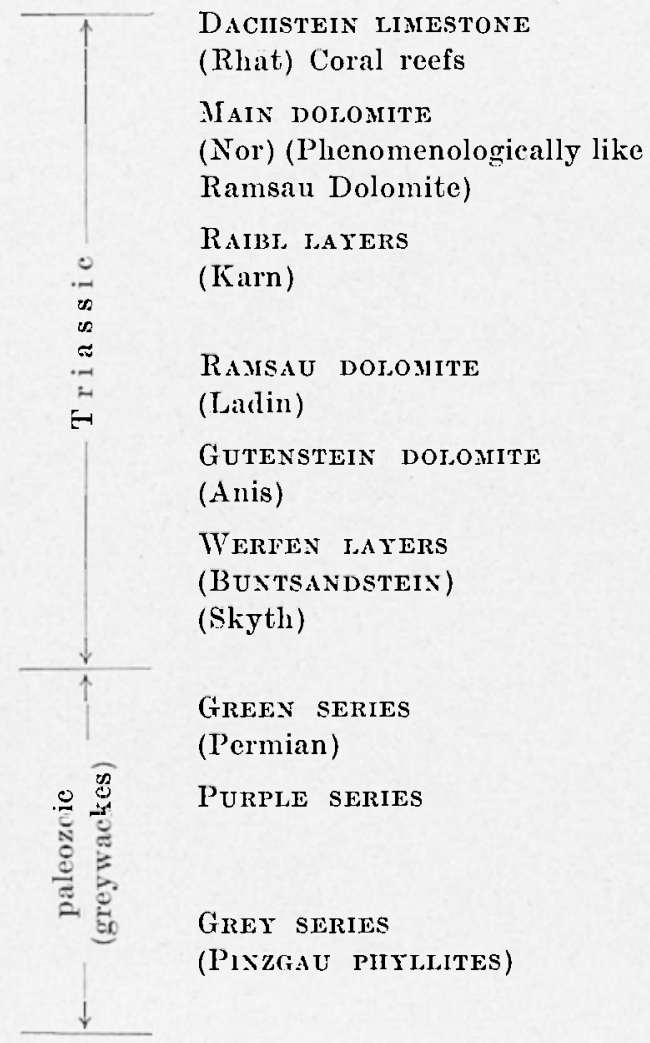

black shale, thin foliation, interspaced with dolomite and limestone

dark blue-gray dolomite, with white veins of feldspar

reddish to yellowish sandstones and quarzites, red to brownyellow arenaceous slates; at the base foliated conglomerates green argillaceous lsates and quartzites

purple phyllites, reddish to purple quartzites, conglomerates and arenaceous slates dark grey phyllites, light-colored quartzitic phyllites, lightcolored sericite slates 


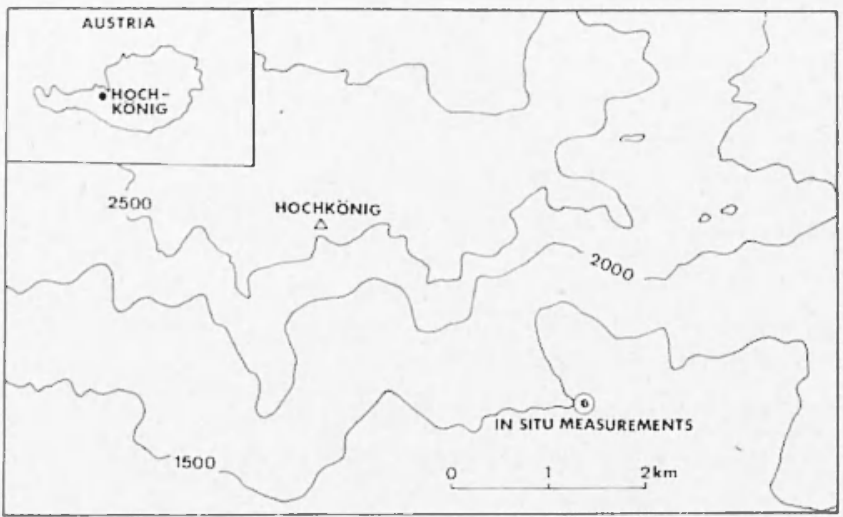

Fig. 1 - Sketch map of the Hochkönig area.

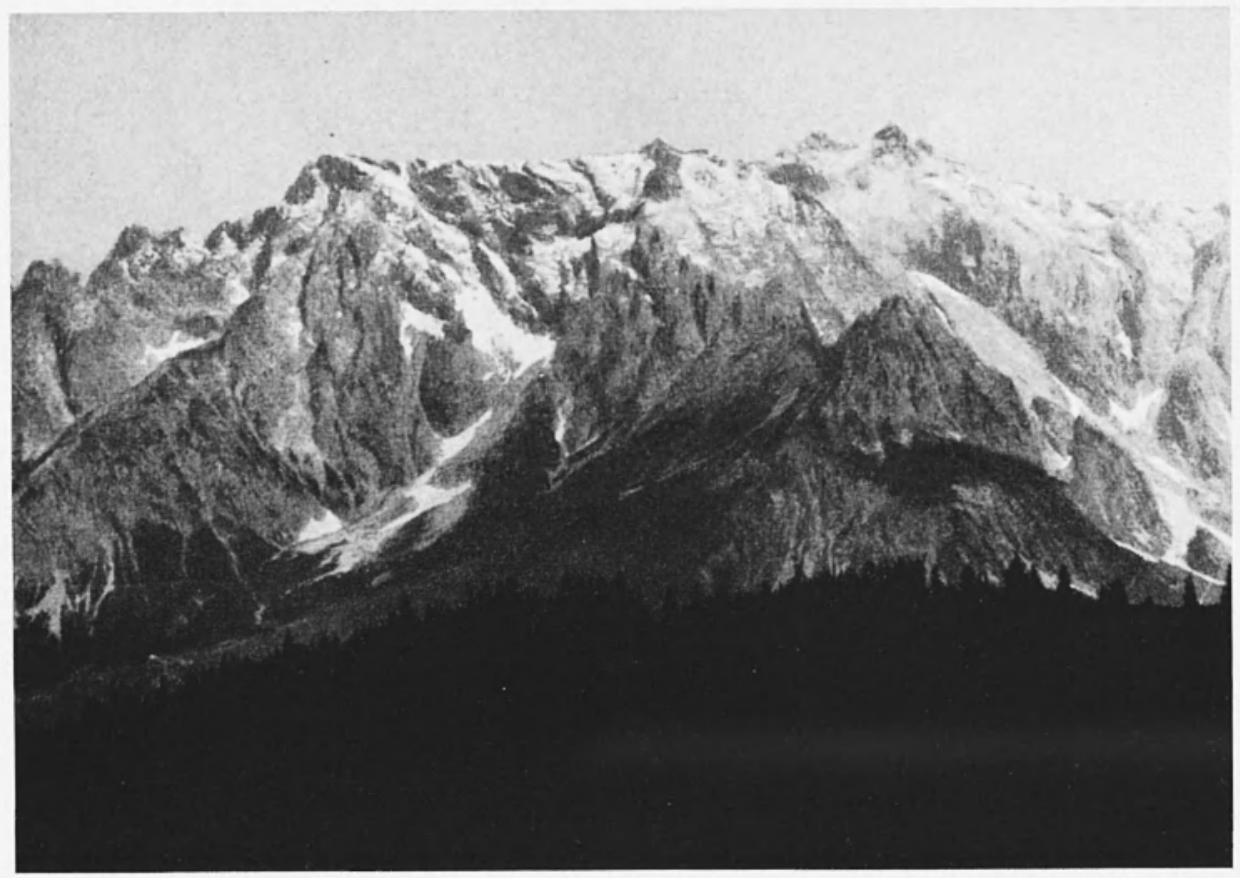

Fig. 2 - General view of the Hochkinig massif. 

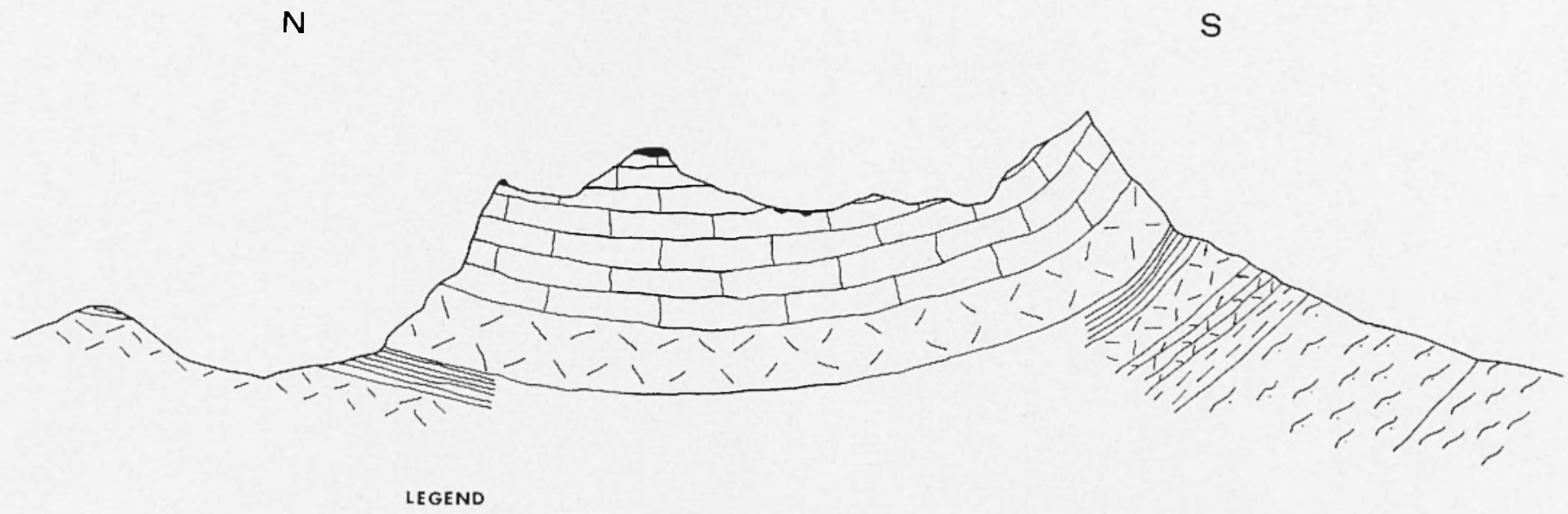

\section{—llas limestone a Jibalbl layers layers}

$1000 \mathrm{nt}$

\section{FIDACHSTEIN}

STRAMSAU DOLOMITE

CIGREEN SERIES

\section{¿IIMAIN DOLOMITE EJGUTENSTEIN}

\section{TIPURPLE SERIES}

Fig. 3 - Schematic geological cross-section of the Hochkönig massif. 


\section{3. - GEOMORPHOLOGICAL TRACES OF THE STRESS SYSTEM}

A very cursory inspertion shows that the whole Hochkonig massif can be separated into various principal domains.

First of all, there is a marked contrast between the base and the superstructure. The base includes the phyllites of the Paleozoic, the superstructure the calcareous and other layers of the Triassic. The division occurs at the Werfen layers.

Second, the alcareous block is divided into a central mass and into spurs which point towards the East, South and West. The central mass shows a "plateau" on top; actually it is an inclined (towards the north) surface with karst features (Fig. 4). The central mass breaks off towards the South in a steep wall (Fig. 5). The "spurs" extend as individual narrow ledges away from the central mass; they are very much broken up by faults and, thus, present the appearance of a series of peaks. The eastern spur, the Mannlwand, is shown in Fig. 6.

Geomorphological investigations indicate, thus, that a basic division has to be male not only between base and superstructure of the massif, but also between the main mass of the massif itself and its spurs. The boundary between the mass itself and a spur is often marked by a deep ravine ("Scharte"), such as the Schranbachscharte between the Hochkonig and the Mannlwand (Fig. 7).

The front wall of the main massif is presumably an exposed fracture surface, in which further traces of fractures may be seen (Fig. 5). The whole gives the impression of a relatively stable mass.

The appearance of a spur, e.g. of the Mannlwand, is different. The whole ledge is greatly fractured, the individual peaks are evidently formed by the intersection of fault surfaces oriented at right angles to the ledge. Moreover, the Mannlwand appears to have slid towards the East, away from the center of the massif, inasmuch as the fault surfaces dipping East are less steep than those dipping West.

\section{4. - STatistics of JoINts}

\section{(I) General remarlis.}

The geomorphological remarks marle above are qualitative. They do, however, indicate the natural divisions that should be made in a 


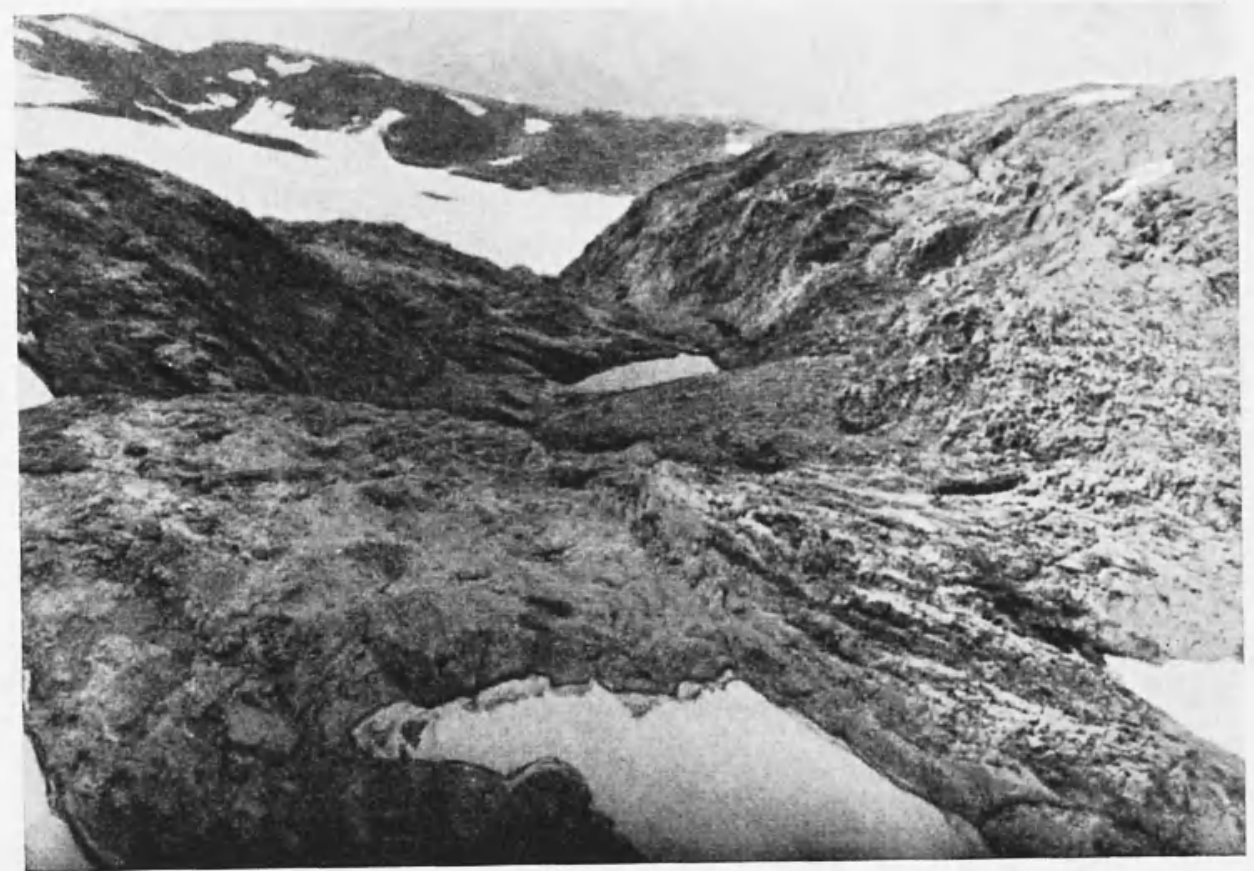

Fig. 4 - Hochkönig "plateau" with karst features.

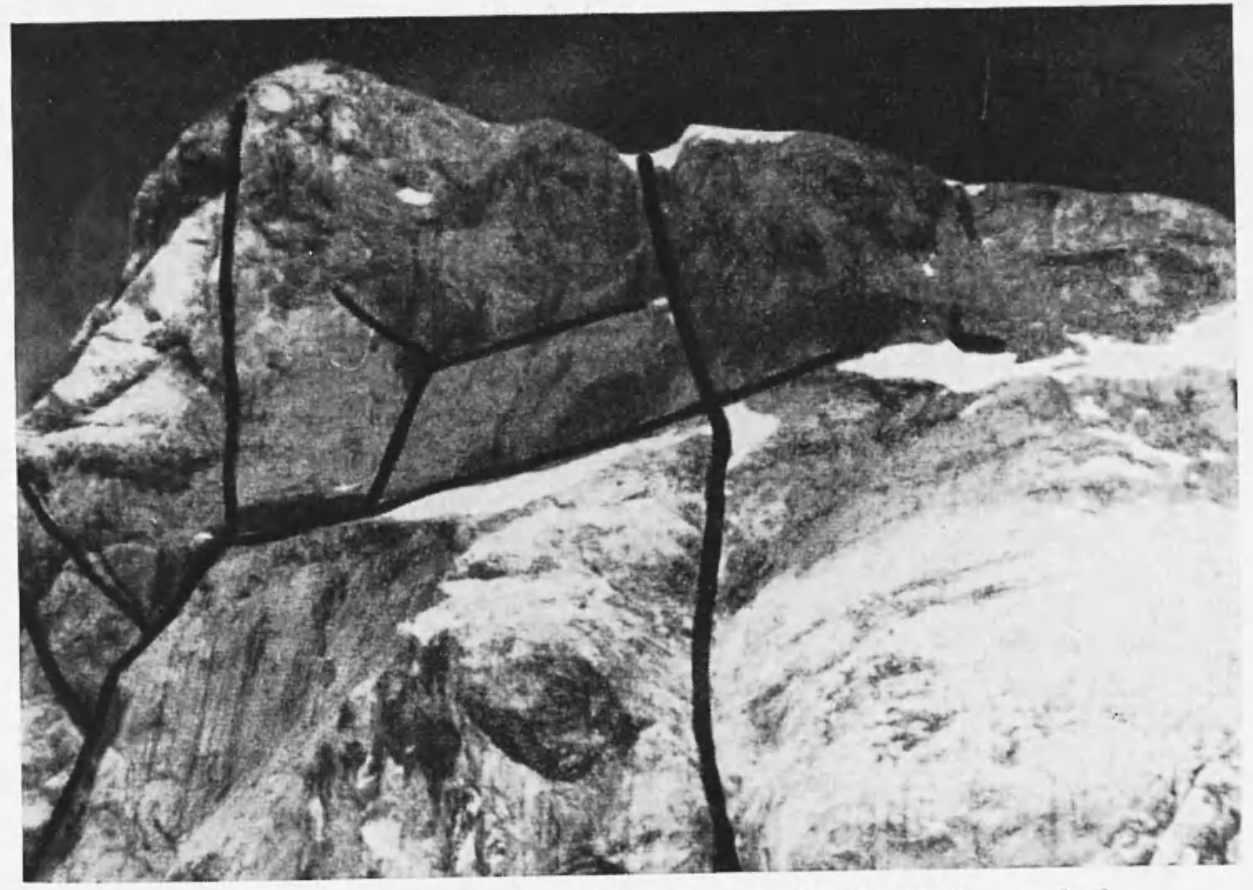

Fig. 5 - South wall of the Hochkönig massif with faults marked. 


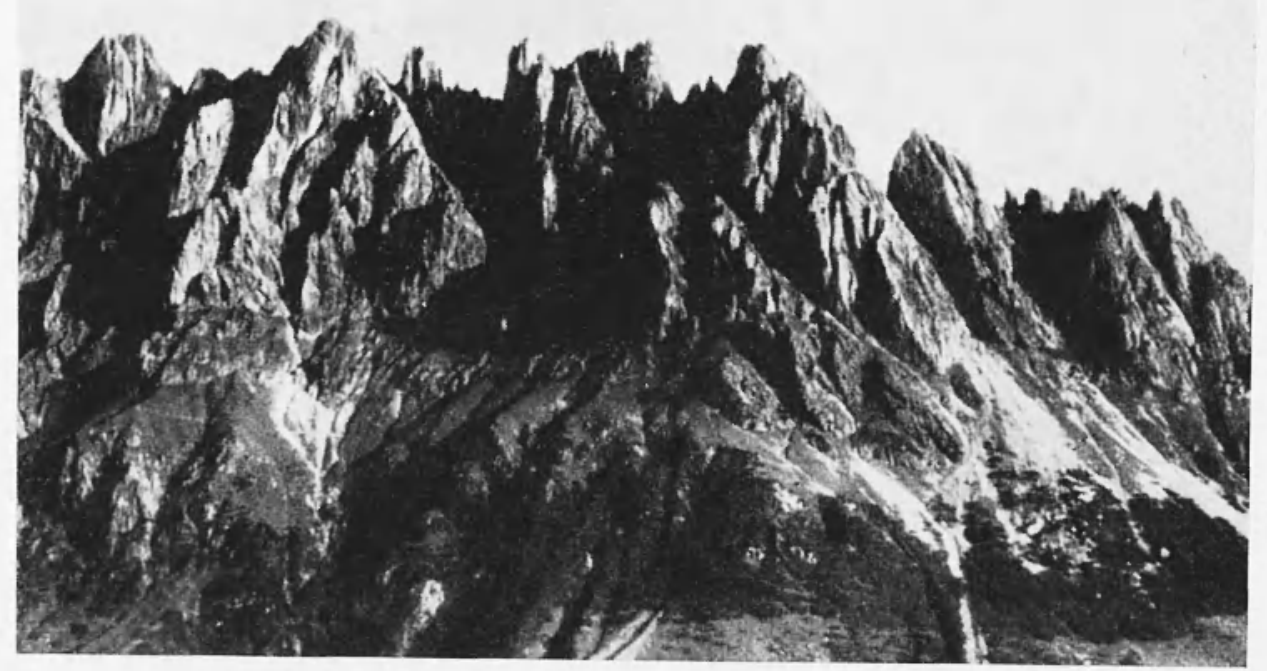

Fig. 6 - The Mannlwand, a spur of the Hochkönig massif.

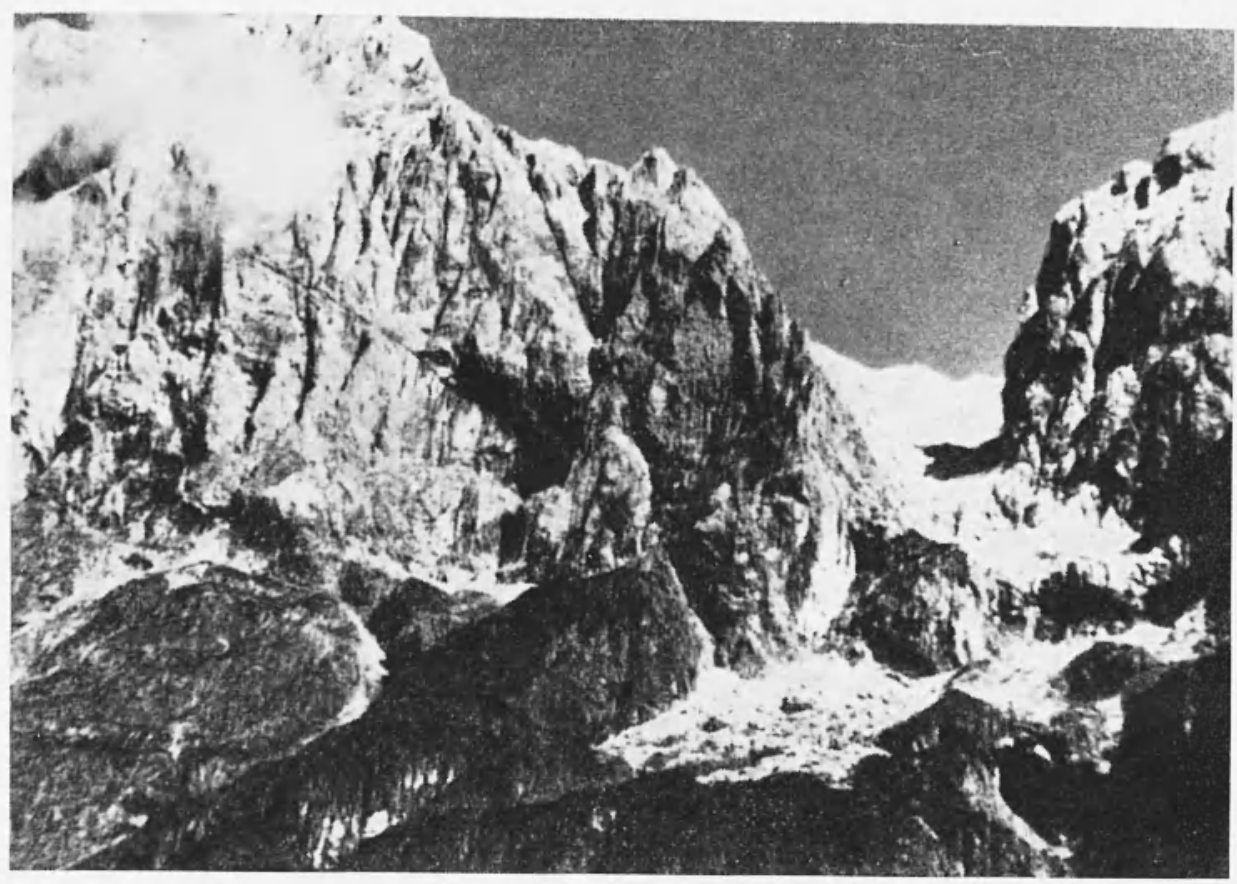

Fig. 7 - The Schranbachscharte separating the main massif from the Mannlwand. 
quantitative analysis of the visible eflects of the tectonic stress field. Evidently, the base, the superstructure of the main massif and the superstructure of the spurs must be treated separately.

\section{(II) Methor of analysis.}

The method used for the analysis was field-mapping of the visible joints in the rock, as described, for instance, by Müller ( $\left.{ }^{3}\right)$.

Accorlingly, the orientation of the joints is fixed using a compass by giving their dip directions (measured $\mathrm{N} \rightarrow \mathrm{E}$ ) and dips. For plotting, the pole of the joint surface is used which is the orientation (azimuth $\mathrm{N} \rightarrow \mathrm{E}$ and plunge) of the normal to the joint surface. The joint parameters are plotterl as a point for each joint on an equalarea projection of the lower half of a unit sphere. The frequency of joints with a certain orientation is given by the density of the corresponding pole-points corresponding to the percentage of the total number of joint directions determinerl as falling on $1 \%$ of the surface of the unit sphere near that direction. Equirlensity lines serve to illustrate the ristribution of the observations.

If there are but two maxima in the equidensity diagram, the corresponding surfaces can be regarded as the conjugate Moln fracture surfaces of a corresponding triaxial stress-system: The fracture surfaces contain the intermediate principal stress direction and are inclined at an angle $\varphi \leqslant 45^{\circ}$ towards the largest compression direction. Hence, the orientation of the largest $(P)$, intermediate $(B)$ and smallest $(\mathbf{T})$ compression direction causing a joint system can be constructed from the joint-rlensity diagram.

\section{(III) The joints in the Hochlonig base.}

In connection with direct stress measurements (see below) the orientation of 114 "joints" in the vicinity of the stress-measurement points in the copper mine at Mitterberg (location see Fig. 1) were measured in the purple series of the greywackes. The resulting density diagram is shown in Fig. 8.

As is seen, there are three density maxima. Howerer, an onthe-spot inspection shower that the SW maximum (pole in the NE quadrant) corresponds to foliation and sedimentation planes, not to joints proper. Hence the conjugate joint system corresponds to the 
maxima at $\mathrm{N} 122 \mathrm{E} / 78^{\circ}$ and $\mathrm{N} 355 \mathrm{E} / 68^{\circ}$. From this, the corresponding $\mathbf{P}, \mathrm{T}$ and $\mathbf{B}$ directions can be calculated; one obtains
P: S $62^{\circ} \mathrm{W} / 33^{\circ}$
$\mathrm{T}: \mathrm{S} 32 \circ \mathrm{E} / 06^{\circ}$
B: $\Upsilon 50 \mathrm{O} / 59^{\circ}$

The angle containing the $\mathbf{P}$-direction at the two fracture planes is $66^{\circ}$.

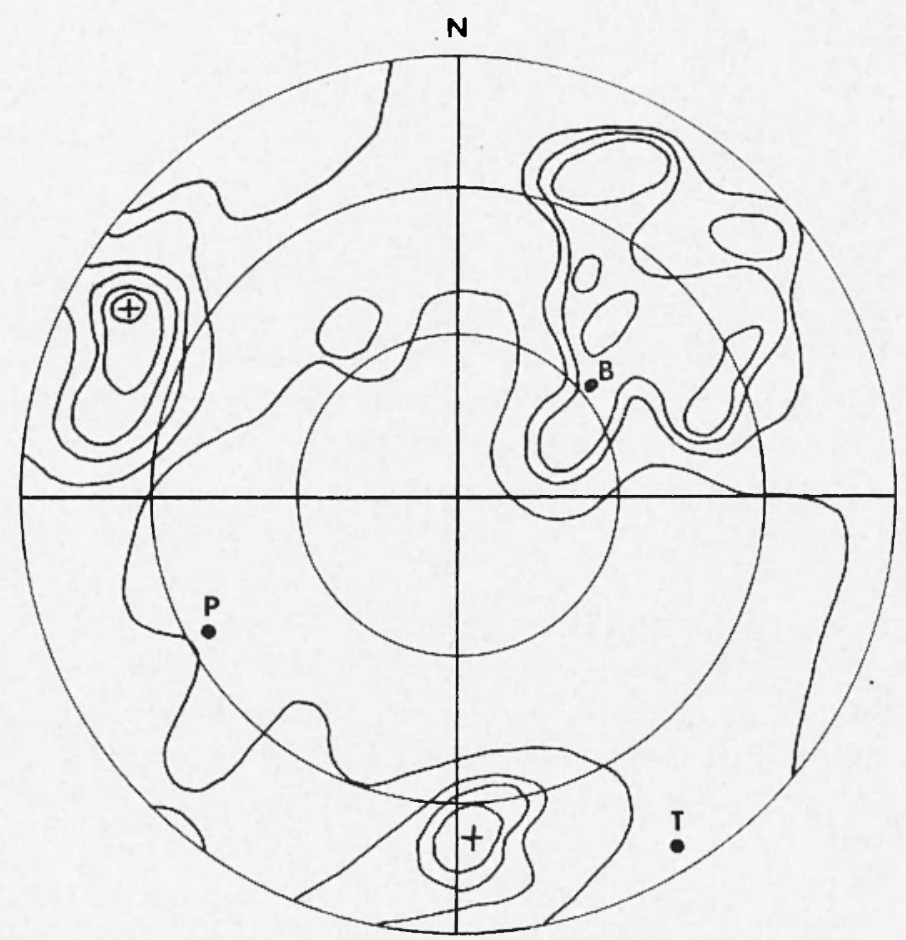

Fig. 8 - Joint density diagram for the Paleozoic base. The density lines are drawn from 114 individual joint measurements for $1,2,4,5$ and $10 \%$.

(IV) The joints in the Hochlonig superstructure.

The orientation of the joints in the superstructure of the Hochkonig massif was measured lluring the field work of 1972 and 1973 of the Institute of Geophysics of the Technical University of Vienna. A total of 1180 joints were measured, mostly on the "plateau". The 
THE ANCIENT AND CONTEMPORARY GEOPIYSICAL STRESS FIELD ETC. 343

resulting density diagram is shown in Fig. 9. It is seen that there are two maxima corresponding to joints oriented $\$ 156^{\circ} \mathrm{E} / 80^{\circ}$ and $\mathrm{N} 25^{\circ} \mathrm{E} / 87^{\circ}$. This corresponds to the following orientations of the $\mathbf{P}, \mathbf{T}$ and $\mathbf{B}$ axes:
P: $\mathrm{N} 24^{\circ} \mathrm{E} / 1^{\circ}$
T: $\mathrm{N} 66^{\circ} \mathrm{W} / 05^{\circ}$
B: $\mathrm{S} 00^{\circ} \mathrm{W} / 78^{\circ}$

Since the angle between the two joint planes is $84^{\circ}$, the identification of $\mathbf{P}$ and $\mathbf{T}$ is not very certain.

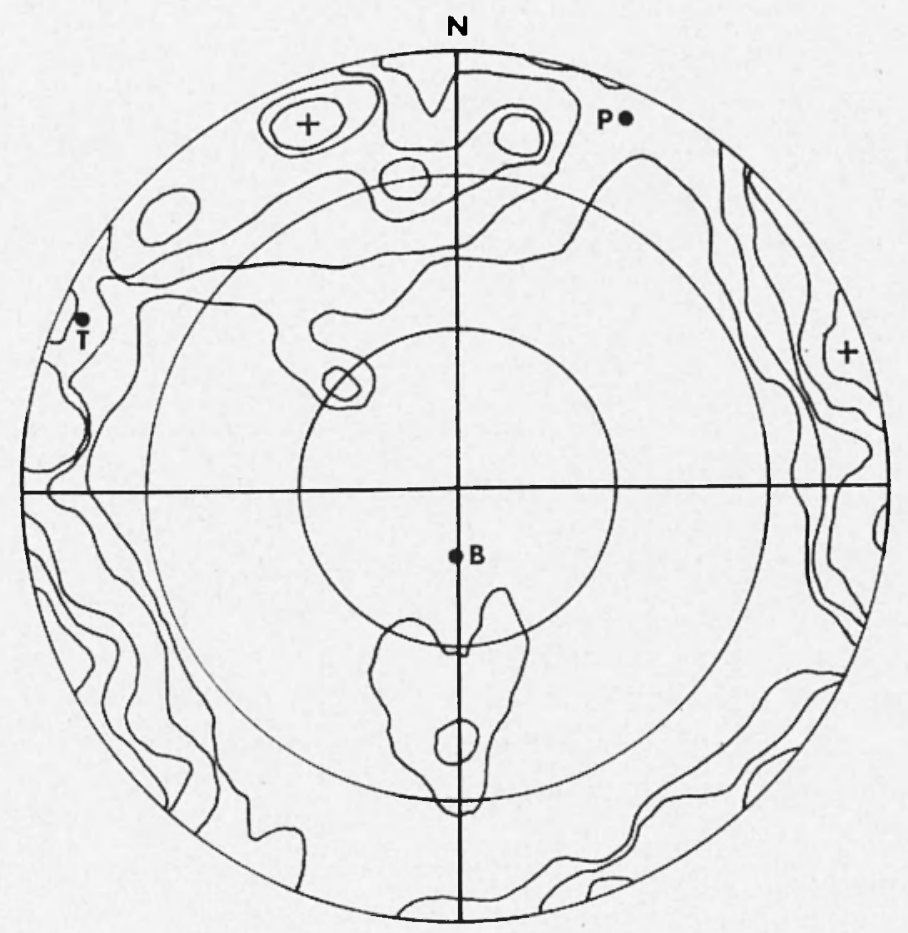

Fig. 9 - Joint density diagram for the Hochkönig superstructure from 1041 individual joint measurements. Equidensity lines for 1, 1.5, 2, 2.5, 3 and $3.5 \%$.

(V) The joints in the Mannlwand.

Finally, the joints in a spur of the Hochkonig massif, viz. in the Mannlwand, were analyzerl. A total number of 1079 measurements 
in layers from the Gutenstein dolomite to the Dachstein limestone were made. The resulting density diagram is shown in Figure 10 . The results are not as unequivocal as in the earlier density diagrams since several maxima exist. However, the maxima at $\mathrm{N} 49^{\circ} \mathrm{E} / 85^{\circ}$ and at $\mathrm{N} 110^{\circ} \mathrm{E} / 64^{\circ}$ seem to be the most prominent ones. The results for $\mathbf{P}, \mathbf{T}, \mathbf{B}$ are then

$$
\begin{aligned}
& \text { P: N } 06^{\circ} \mathrm{W} / 20^{\circ} \\
& \text { T: S } 78^{\circ} \mathrm{W} / 17^{\circ} \\
& \text { B: S } 51^{\circ} \mathrm{E} / 63^{\circ}
\end{aligned}
$$

The angle enclosing $\mathbf{P}$ is $60^{\circ}$.

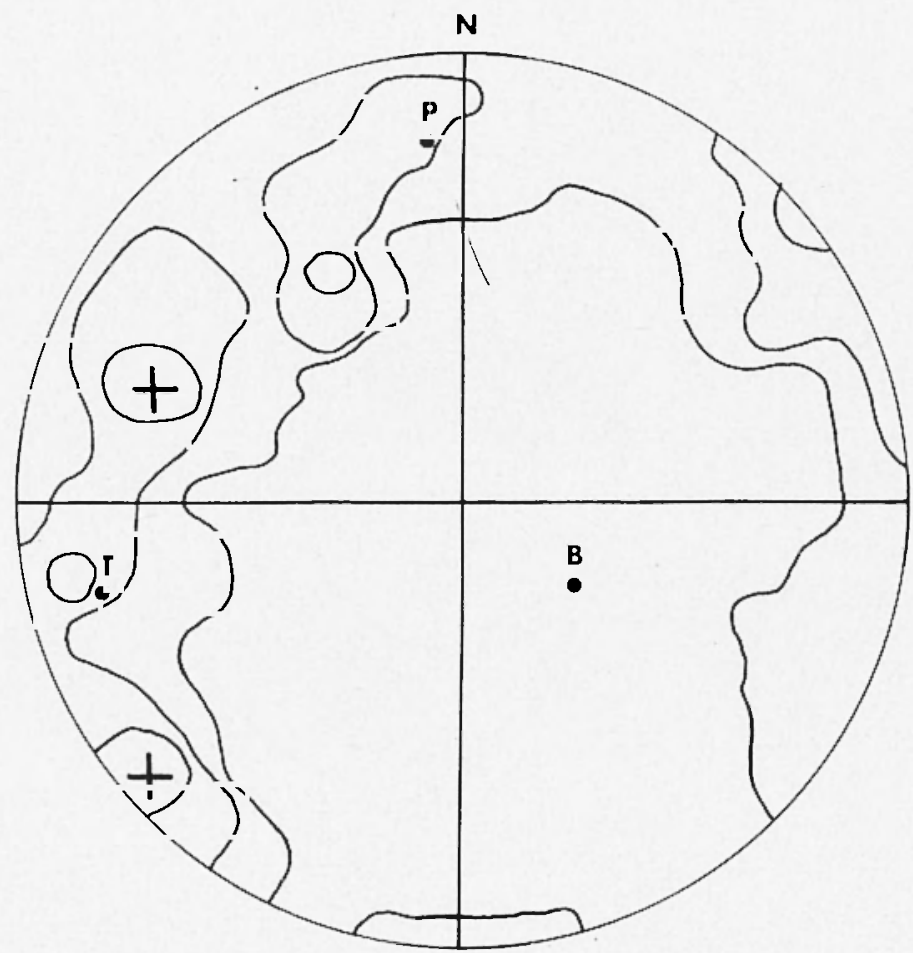

Fig. 10 - Joint density diagram for the Mannlwand from 1180 individual joint measurements. Equidensity lines for 1, 2 and $3 \%$.

\section{5. - IN SITU STRFSS MEASUREMENTS}

Stresses were also determined in situ in a drive of the copper mine of Mitterberg 750 meters below the surface. The general sketch 
map (Figure 1) of the area shows the location of the stress measurements. In total three holes were drilled and the prevailing stresses were determined by the "doorstopper" methor. The details of the measurements were described by Brïckl and Scheidegger (1) and by Brückl, Roch and Scheidegger $\left.{ }^{2}\right)$. Since three holes were drilled, it was in principle possible to determine the entire stress tensor at the measurement-point. However, it turned out that the absolute values obtained were not significant owing to too much scattering. Solely, the direction of maximum compression could be determined, it turned out to be

$$
\text { P: } \mathbf{S} 23^{\circ} \mathrm{E} / 70^{\circ} \text {. }
$$

The $\mathbf{B}$ and $\mathbf{T}$ directions normal to the $\mathbf{P}$ directions could not be determined individually; however, it could be shown that the value of the minimum and intermediate principal pressures reached only $74 \pm 11$ per cent of the maximum principal pressure.

\section{6. - Significance of REsults}

Even a cursory inspection of the adduced results shows that there is no direct correlation between the stress systems evident in the joints of the Hochkonig superstructure and Mannlwand, of the base and that evident in the direct stress measurements. The various results are collated in Table 2 and Figure 11.

The stress system found by the in-situ measurements is most easily explained. The direction of the maximum pressure (S 2305/70 $)$ points directly to the summit of the Hochkonig, so that the orientation of the presently active stress system is apparently entirely conditioned by gravity effects caused by the overburden. The maximum compression is due to the overburden pressure caused by the calcareous Hochkonig block; normal to the maximum compression direction, a stress relief takes place which is obviously due to the presence of relatively soft Paleozoic greywacke layers lying beneath the solid calcareous block forming the Hochkonig massif. The presently acting stresses, therefore, are entirely in conformity with the present geological makeup of the area and with its topography. 
The joints, on the other hand, apparently are the expression of earlier stress systems. In all cases, the $\mathbf{B}$ axes plunge steeply downward. In the Hochkönig block as well as, more pronouncerly, in the Mamnlwand the smallest pressure is approximately in an East-West direction. This is also expressed in the geomorphic appearance of the Iamnlwand. Correspondingly, the largest compression is more or less in a North-South direction, corresponding, presumably, to the thrust by which the Alps were formed.

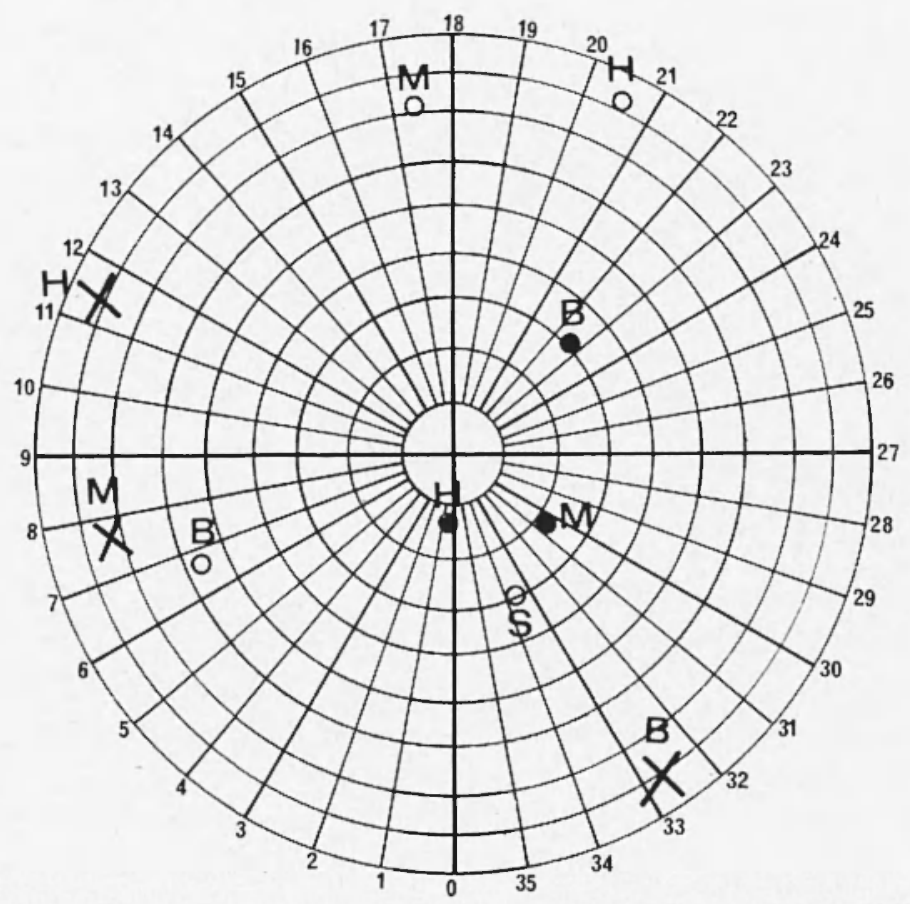

Figr. 11 -Combined diagram for the $P(0), T(X)$ and $B(\bullet)$ directions: H IIochkonig superstructure, $\mathbf{M}$ Nannlwand, B Paleozoic base, $\mathbf{S}$ in-situ measurements.

The joints in the Paleozoic base represent a different stress-pattern altogether. The B-rlirection still plunges steeply downward, although somewhat less so than in the limestone, but the $\mathbf{P}$ and $\mathbf{T}$ rirections are rotated by about $60^{\circ}$ in a clockwise direction. One must infer that the joints in the base correspond to an earlier stress 
THE ANCIENT AND CONTEMPORARY GEOPIISICAL STRESS FIELI ETC. 347

Table 2 - RESULTS FRON STRESS DETERMINATIONS

\begin{tabular}{|c|c|c|c|c|}
\hline Locality & $\mathbf{P}$ & $\mathbf{T}$ & B & $\begin{array}{c}\text { angle } \\
\text { enclosing } P\end{array}$ \\
\hline Greywackes & $\mathrm{S} 62^{\circ} \mathrm{W} / 33^{\circ}$ & $\mathrm{S} 32^{\circ} \mathrm{E} / 06^{\circ}$ & $\mathrm{N} 50^{\circ} \mathrm{E} / 59^{\circ}$ & $66^{\circ}$ \\
\hline $\begin{array}{l}\text { Iimestone } \\
\text { superstruc. }\end{array}$ & $\mathrm{N} 24^{\circ} \mathrm{E} / 10^{\circ}$ & $\mathrm{N} 66^{\circ} \mathrm{W} / 05^{\circ}$ & $\mathrm{S} 00^{\circ} \mathrm{W} / 78^{\circ}$ & $84^{\circ}$ \\
\hline Mannlwand & $\mathrm{N} 06^{\circ} \mathrm{W} / 20^{\circ}$ & $\mathrm{S} 78^{\circ} \mathrm{W} / 17^{\circ}$ & $\mathrm{S} 51^{\circ} \mathrm{E} / 63^{\circ}$ & $60^{\circ}$ \\
\hline In-situ & $\mathrm{S} 23^{\circ} \mathrm{E} / 70^{\circ}$ & $?$ & $?$ & $q$ \\
\hline
\end{tabular}

system than that which created the joints in the limestone. In conformity with this, it has been observed that the location of the copper occurrences cannot be inferred from an investigation of the tectonic and geological features of the superstructure: there is no correlation.

\section{7. - Conclusions}

Finally, the results of the present investigation can be summarizerl as follows:

(I) The Hochkonig massif consists of two distinct geological units: The Paleozoic base and the Triassic superstructure.

(II) The stress system which produced the joints and dykes in the Paleozoic base ean be ascertained; it has a specific orientation which is distinetly its own.

(III) The stress system which prodnced the joints in the Triassic superstructure is in conformity with the general view of the formation of the Alps (North-Sonth thrust). In spite of the different geomorphic appearance of the main massif and its spurs, the stress system which formed the joints and faults in both is basically the same.

(IV) The stress system which is active at the present time is entirely caused by gravitational effects of a heavy solicl overbur(len (limestone, dolomite) lying on a soft (greywacke) substratum. 


\section{REFERENCES}

(1) BRÜCKL, E. and SCIIEIDEGGER, A. E., 1974. - In situ stress measurements in the copper mine at Mitterbery, Lustria. "Rock Mechanics" (in press).

(2) BrüCKL, E., Rocir, H. K., and ScIIEIdEgGer, A. E., 1974. - Significance of stress measurements in the Hochlionig Massif in A ustria. Proc. Symposium on Recent Crustal Movements, Zurich.

(3) MÜller, L., 1963. - Der Felsbau. 624 pp. Stuttgart: Ferdinand Enke Verlag. 